ПРОХОРОВ В. М., к.т.н. (УкрДУЗТ), КАЛАШНІКОВА Т. Ю., к.Т.Н., (УкрДУЗТ), МУРАХОВСЬКИЙ Т. О., заступник директора філії ЦТЛ АТ «Укрзалізниця», ЛОТИШ Ю. О., магістрант, (УкрДУЗТ), ШАБАТУРА В. В., магістрант (УкрДУЗТ)

\title{
Розробка математичної моделі для оптимізації плану формування швидкісних пасажирських поїздів
}

Завдання підвищення конкурентоспроможності швидкісних пасажирських перевезень в Україні з кожним роком лише загострюється, адже стрімко зростає рівень конкурениї на цььму ринку із автомобільним $i$ авіаційним транспортом. Вирішення завдання збереження існуючого пасажиропотоку, залучення нових пасажирів на швидкісних залізничних лініях з одночасною мінімізацією експлуатаційних витрат та не підвищення тарифів є можливим за рахунок впровадження сучасних технологій управління маршрутами пасажирських поїздів. Запропоновано задачу тактичного рівня управління пасажирськими перевезеннями для визначення оптимальних маршрутів пасажирських поїзів з метою максимізації рівня населеності составів, покращення показників використання рухомого складу та максимізачії пасажиропотоків. Сформовано математичну модель для розрахунку плану формування швидкісних пасажирських поїзів, яка дозволяє реалізувати максимальний пасажиропотік, одночасно мінімізуючи експлуатаційні витрати. Для оптимізаціі моделі було запропоноване використання математичного апарату генетичних алгоритмів.

Ключові слова: швидкісні пасажирські перевезення, населеність пасажирського поӥза, план формування пасажирських поїдів, генетичні алгоритми.

\section{Постановка проблеми}

Сучасне суспільство характеризується

інтенсивними комунікаційними процесами. Забезпечення зростання мобільності населення $\epsilon$ одним із вирішальних факторів стратегії розвитку економіки країни. На сьогодні у сфері транспортного обслуговування залізничні пасажирські перевезення $\epsilon$ одним із найбільш ефективних видів транспорту, що дає змогу забезпечити необхідну швидкість, комфорт, надійність i безпеку перевезень 3 мінімальними витратами та 3 урахуванням ресурсних обмежень i умов навколишнього середовища.

Однією із важливих складових системи організації пасажирських перевезень $є$ процес планування. Процес розробки технічного плану передбачає на першому етапі визначення обсягів перевезень на основі прогнозування та моделювання пасажиропотоків за напрямками і дільницями мережі, на другому етапі визначається раціональний план формування пасажирських поїздів, після чого, на останньому етапі складається схема обігу пасажирських составів на полігонах мережі та розробляється графік пасажирського руху.

Механізм формування попиту на швидкісні залізничні пасажирські перевезення потребує відносної постійності в наданні транспортних послуг, зокрема уникання небажаних частих змін існуючого
\end{abstract}

розкладу руху поїздів. Тому сучасна система управління виключила 3 технічного планування складний процес постійного перерахунку параметрів системи організації перевезень. Вона обмежується встановленням додаткових потреб у перевезеннях на основі мінімального корегування та послідовної зміни протягом певного періоду часу діючої раціональної системи руху поїздів до деякої оптимально перспективної.

Практичний досвід організації пасажирських перевезень в умовах конкуренції на ринку пасажирських перевезень вказує на неможливість ефективної реалізації всіх складових планування пасажирських перевезень без застосування сучасних логістичних технологій, маркетингових досліджень та інтелектуальних систем.

\section{Аналіз останніх досліджень і публікацій \\ Швидкісні залізничні пасажирські перевезення для багатьох, навіть розвинених, країн $є$ відносно новим видом перевезень, хоча вони стрімко розвиваються. Цим обумовлено відсутність єдиного підходу до вироблення принципів i створення технологій експлуатаційного управління системами швидкісних залізничних пасажирських перевезень. Отже,}

(ㄱ В. М. Прохоров, Т. Ю. Калашнікова, Т. О. Мураховський, Ю. О. Лотиш, В. В. Шабатура, 2019 
створення теоретичних підходів для формування технологій управління у сфері швидкісних залізничних пасажирських перевезень $\epsilon$ актуальною темою наукових досліджень. Широкий спектр питань цих досліджень обумовлений значною кількістю специфічних проблем, що постають на шляху створення таких систем. Одним із важливих питань на шляху формування швидкісних залізничних пасажирських систем у країнах Європи є узгодженість їх функціонування на полігонах, що включають одразу декілька залізничних систем країн Європейського Союзу. В [1] розглядається задача побудови розкладу 3 урахуванням взаємного впливу таких факторів, як якість розкладу і транспортні вимоги. Дослідження [2, 3] присвячені побудові якісного розкладу руху високошвидкісних поїздів по магістральних лініях 3 одночасною оптимізацією кількості зупинок з метою збільшення їх пропускної спроможності. У $[4,5]$ також докладно розглядається задача підвищення пропускної спроможності високошвидкісних залізничних ліній в умовах постійно зростаючого попиту на пасажирські перевезення. Всі ці публікації містять математичні моделі, оптимізацію яких було здійснено класичними методами: лінійного програмування, генерації стовпчиків, гілок та границь. У [6] запропоновано модель розрахунку плану формування пасажирських поїздів та сучасний механізм іiі оптимізації на основі рою часток. Багато уваги приділено проблемам проходження пасажиропотоків через станції при здійсненні перевезень із пересадками. Однак у цій статті не було враховано специфіки організації швидкісних пасажирських перевезень.

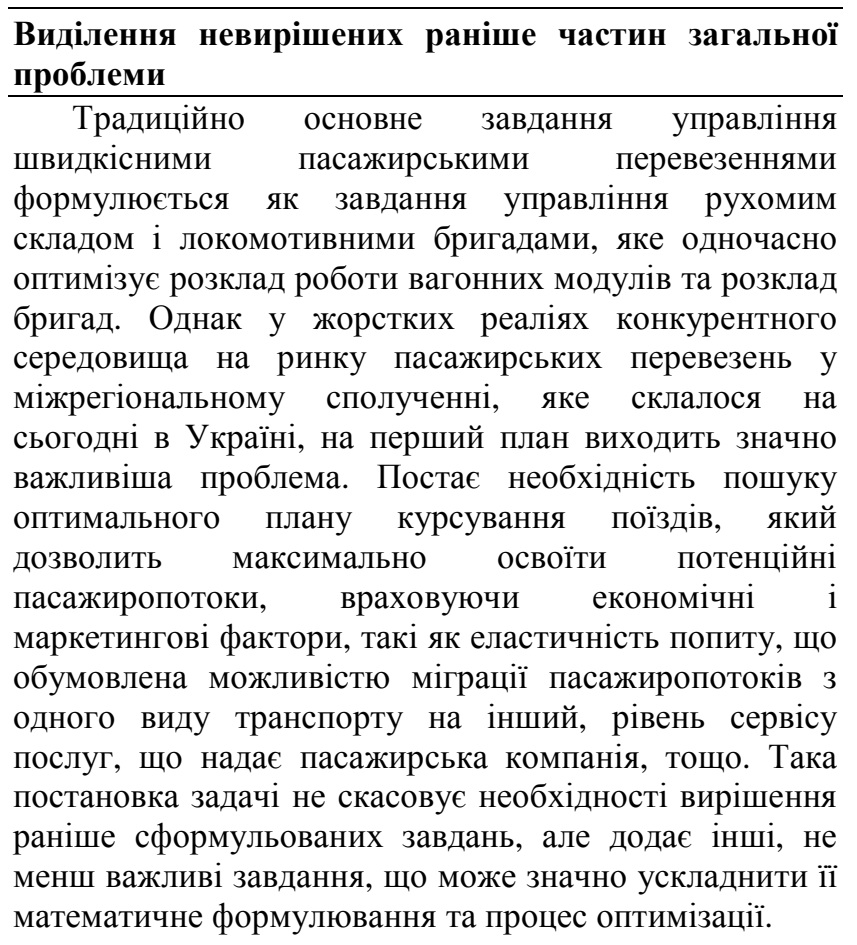

Формулювання цілей

Метою дослідження $є$ формування і вирішення тактичного завдання управління швидкісними пасажирськими перевезеннями в умовах мінливості пасажиропотоків i конкуренції 3 іншими видами транспорту шляхом формування моделі розрахунку раціонального плану формування швидкісних пасажирських поїздів.

\section{Викладення основного матеріалу дослідження}

Застосування логістичної концепції управління залізничним пасажирським комплексом за умови максимального задоволення платоспроможного попиту населення на перевезення дасть змогу поновому поставити та вирішити найбільш важливі завдання організації швидкісних пасажирських перевезень, у тому числі удосконалити існуючу технологію перевезень, надавши їй властивості адаптації, оптимізувати розробку та уточнення плану формування, схем обігу та графіка руху пасажирських поїздів, і на цій основі суттєво підвищити якість перевізного процесу, знизивши при цьому експлуатаційні витрати на нього.

Таким чином, у сучасних умовах ще на рівні побудови плану формування швидкісних пасажирських поїздів необхідно враховувати критерії витрат, що складають собівартість перевезень, такі як мінімізація пробігу вільних місць, мінімізація довжини маршрутів пасажирських поїздів, але головним критерієм на цьому етапі розвитку пасажирських перевезень в Україні має стати критерій освоєння пасажиропотоків з наданням саме того рівня сервісу, який потрібен кожній категорії пасажирів 3 урахуванням відповідності цінової політики до рівня платоспроможності пасажирів. Специфікою організації високошвидкісних пасажирських залізничних перевезень $\epsilon$ те, що їх мета полягає не у задоволенні попиту на перевезення пасажирів усіх категорій, а у максимізації прибутків залізничної компанії-оператора за рахунок залучення пасажирів, які згодні платити за певний рівень комфорту, одним із головних факторів якого, зокрема, є швидкість переміщення.

При цьому в розрахунки можуть бути закладені додаткові умови і обмеження: щодо завантаження станції, пропускної спроможності залізничних ліній, але вони у сучасних умовах конкурентної боротьби $є$ набагато менш важливими.

Тоді цільову функцію моделі можна записати таким чином: 
$C(x)=\theta_{1} \sum_{i=1}^{n}\left(l_{i} \cdot e_{n \kappa u} \cdot \operatorname{sgn}\left(\sum_{j=1}^{k} x_{i j}\right)\right)+\theta_{2} \sum_{i=1}^{n}\left(\sum_{s=1}^{S_{i}} \sum_{j=1}^{k}\left(\left(a_{i}-x_{i j} \cdot P_{j} \cdot \psi_{i s j}\right) \frac{l_{s i}}{l_{i}}\right)\right)^{2}+$

$+\theta_{3} \cdot c_{\kappa в} \sum_{j=1}^{k}\left(P_{j}-\sum_{i=1}^{n} x_{i j} \cdot P_{j}\right)$

де $e_{n \kappa м}-$ витратна ставка за 1 поїздо-кілометр, грн;

$l_{i}$ - довжина маршруту $i$-го поїзда;

$n$ - потужність множини поїздів, що налічує всі можливі маршрути поїздів, що розглядаються;

$k$ - потужність множини струменів пасажиропотоків;

$x_{i j}$ - визначає частку пасажиропотоку $j$, який буде перевезений поїздом $i$;

$a_{i}$ - максимальна кількість місць $i$-го поїзда;

$P_{j}$ - розмір $j$-го пасажиропотоку;

$l_{s i}$ - довжина $s$-ї дільниці маршруту $i$-го поїзда;

$\psi_{i s j}-$ набуває значення 1 , якщо по $s$-й дільниці поїздом $i$-го маршруту може перевозитися $j$-й пасажиропотік, тобто якщо станція посадки і станція висадки пасажирів $j$-го пасажиропотоку належать до множини станцій $i$-го маршруту і станція посадки розташована раніше станції висадки відповідно до напрямку руху поїзда, в іншому випадку набуває значення 0;

$S_{i}$ - кількість дільниць між зупинками поїзда $i$-го маршруту;

$c_{\kappa в}$ - середня вартість квитка;

$\theta_{1} . . \theta_{3}-$ вагові коефіцієнти.

Перший доданок цільової функції відповідає критерію мінімізації довжини пробігу пасажирських поїздів, другий доданок відповідає критерію мінімізації пробігу вільних місць і третій доданок відповідає критерію освоєння пасажиропотоків. Таким чином, усі ці три критерії у цільовій функції зведені до суперкритерію із використанням методу згортки за допомогою вагових коефіцієнтів. Вагові коефіцієнти доцільно обирати експертним шляхом. Критерій мінімізації пробігу вільних місць подано у вигляді нелінійної функції, квадратична залежність використана для прогресивного зростання значення функції при збільшенні сумарної величини пробігу вільних місць. Сумарна величина пробігу вільних місць залежить як від кількості місць, так і від величини пробігу. Але оскільки критерій освоєння пасажиропотоків $є$ найбільш важливим, тому доцільно обирати ваговий коефіцієнт, що відповідає даному критерію таким чином, щоб його величина перевищувала значення суми вагових коефіцієнтів двох інших критеріїв.

Крім того, на матрицю змінних $x$ необхідно накласти обмеження:

$\sum_{i=1}^{n} x_{i j} \leq 1, \quad \forall j, j=1 . . k$

що означає, що сума часток одного пасажиропотоку, які прямують до станції призначення у різних поїздах, не може перевищувати 1.

Ще одне обмеження на матрицю змінних $x$ можна записати таким чином:

$$
\sum_{j=1}^{k}\left(x_{i j} \cdot P_{j} \cdot \psi_{i s j}\right) \leq a_{i}, \quad \forall i, \forall s, i=1 . . n, s=1 . . S_{i}
$$

Воно забезпечить неперевищення сумарною кількістю пасажирів, що належить до різних пасажиропотоків і одночасно прямують у складі $i$-го поїзда по $s$-й дільниці його маршруту. Під різними пасажиропотоками розуміються потоки, у яких не збігаються початкові i/або кінцеві пункти прямування пасажирів, однак певні ділянки маршрутів таких пасажиропотоків можуть збігатися.

\section{Висновки}

Організація високошвидкісних залізничних пасажирських перевезень потребує застосування підходів, які $\epsilon$ відмінними від підходів, які використовуються при організації пасажирських перевезень у далекому та міжрегіональному сполученні. Врахування критерію населеності високошвидкісних поїздів, який враховує відстань пробігу зайнятих і порожніх місць при побудові плану формування поїздів, надасть можливість підвищити точність розрахунків. Застосування сформованої моделі розрахунку плану формування пасажирських поїздів надасть можливість не лише підвищити показники використання рухомого складу, а й збільшити дохідність пасажирської компанії-оператора за рахунок залучення більшої кількості пасажирів. 
Список використаних джерел

1. Chierici, A., Cordone R., Maja R. The demanddependent optimization of regular train timetables. Electronic Notes in Discrete Mathematics. 2004. Vol. 17. P. 99-104.

2. Yue Yixiang, Wang Shifeng, Zhou Leishan, Tong Lu, Rapik Saat M. Optimizing train stopping patterns and schedules for high-speed passenger rail corridors. Transportation Research Part C: Emerging Technologies. 2016. Vol. 63. P. 126-146.

3. Wang Jin, Zhou Leishan, Yue Yixiang, Tang Jinjin, Bai Zixi. Optimizing high-speed railroad timetable with passenger and station service demands: A case study in the Wuhan-Guangzhou corridor. Journal of advanced transportation. 2018. Vol. 1. P. 1-18.

4. Wu J., Nash C., Wang D. Is high speed rail an appropriate solution to China's rail capacity problems? Journal of Transportat Geography. 2014. Vol. 40. P. 100-111.

5. Wang J.J., Xu J., He J. Spatial impacts of high-speed railways in China: a total-travel-time approach. Environment and Planning. 2013. Vol. A 45. P. 22612280.

6. Бутько Т. В., Прохорченко А. В., Шандер О. Е. Розробка плану формування пасажирських поїздів на основі методу роя часток. Вісник НТУ «ХПI». 2011. № 54. С.70-76.

Prokhorov V.M.

Kalashnikova T. Yu., Murakhovskyi T. O., Lotysh Yu. O., Shabatura V. V. Development of a mathematical model to optimize the train formation plan of high-speed passenger trains.

Abstract. The task of increasing the competitiveness of high-speed passenger transportation in Ukraine every year is only exacerbated, as the level of competition in this market with road and air transport is growing rapidly. The solution to the problem of maintaining the existing passenger traffic and attracting new passengers on the high-speed rail lines while minimizing operating costs and not increasing tariffs is possible due to the introduction of modern technologies for managing passenger train routes. The task of tactical level of management of passenger transportation is proposed to determine the optimal routes of passenger trains in order to maximize the population level of trains, improve the use of rolling stock and maximize passenger traffic. A mathematical model has been formed to calculate the plan for the formation of high-speed passenger trains, which allows to realize the maximum passenger flow while minimizing operating costs. This model is built using the classic cost method. The peculiarity of this model is that it simultaneously takes into account the technological costs that depend on the route of trains and the number of trains involved and the demand for transportation, taking into account tariffs and ticket prices. The developed model is proposed to be used as a target function for solving the problem of calculating the plan of formation of high-speed passenger trains. Optimization of this target function will allow to create a detailed plan of passenger transportation at the same time taking into account both technological costs and profits of the railway company from ticket sales. To optimize the model, it was suggested to use a mathematical apparatus of genetic algorithms. This mathematical apparatus, in contrast to the classical methods of optimization, allows you to flexibly formulate and take into account the constraints of different types, due to the technological parameters of the transport process and the original data.

Keywords: high-speed passenger transportation, occupancy of the passenger train, formation plan of passenger trains, genetic algorithms.

\section{Прохоров В. Н., Калашникова Т. Ю., Мураховский Т. А., Лотыш Ю. А., Шабатура В. В. Разработка математической модели для оптимизации плана формирования скоростных пассажирских поездов.}

Аннотация. Задача повышения конкурентоспособности скоростных пассажирских перевозок в Украине с каждым годом только усугубляется, поскольку стремительно повышается уровень конкуренции на этом рынке с автомобильным и авиационным транспортом. Решение задачи сохранения существующего пассажиропотока, привлечения новых пассажиров на скоростных железнодорожных линиях с одновременной минимизацией эксплуатационных расходов и неповышения тарифов возможно за счет внедрения современных технологий управления маршрутами пассажирских поездов. Предложена задача тактического уровня управления пассажирскими перевозками для определения оптимальных маршрутов пассажирских поездов с целью максимизации уровня населенности составов, улучшения показателей использования подвижного состава и максимизации пассажиропотоков. Сформирована математическая модель для расчета плана формирования скоростных пассажирских поездов, которая позволяет реализовать максимальный пассажиропоток, одновременно минимизируя эксплуатационные расходы. Для оптимизации модели было предложено использование математического аппарата генетических алгоритмов.

Ключевые слова: скоростные пассажирские перевозки, населенность пассажирского поезда, план формирования пассажирских поездов, генетические алгоритмы. 
Prokhorov Victor Mykolaiovych, Ph.D., Department of Management of operational work, Ukrainian State University of Railway Transport, Kharkiv, Ukraine. E-mail: prokhorov@kart.edu.ua ID ORCID https://orcid.org/0000-0001-8963-6467

Kalashnikova Tetiana Yuriivna, Ph.D., Department of Management of operational work, Ukrainian State University of Railway Transport, Kharkiv, Ukraine. E-mail: bulavina_ty@ukr.net ID ORCID https://orcid.org/0000-0001-6563-5945

Murakhovskyi Timofii Oleksandrovych, Deputy Director of the CTL JSC "Ukrzaliznytsia” branch, Kyiv, Ukraine. E-mail: $\quad$ murakhovskyi@i.ua ID ORCID https://orcid.org/0000-0002-6148-7161

Lotysh Yuliia Oleksandrivna, master student, Department of Management of operational work, Ukrainian State University of Railway Transport, Kharkiv, Ukraine. E-mail: $\quad$ lotyshyuliia@i.ua ID ORCID https://orcid.org/0000-0002-9630-9090

Shabatura Vladyslav Viktorovych, master student, Department of Management of operational work, Ukrainian State University of Railway Transport, Kharkiv, Ukraine. E-mail: solinawow@gmail.com ID ORCID https://orcid.org/0000-0003-0618-3648
Прохоров Віктор Миколайович, к.т.н., кафедра управління експлуатаційною роботою, Украӥнський державний університет залізничного транспорту, Харків, Україна. E-mail: prokhorov@kart.edu.ua ID ORCID https://orcid.org/0000-0001-8963-6467

Калашнікова Тетяна Юріївна, к.т.н., кафедра управління експлуатаційною роботою, Украӥнський державний університет залізничного транспорту, Харків, Украӥна. E-mail: bulavina_ty@ukr.net ID ORCID 0000-0001-6563-5945

Мураховський Тимофій Олександрович, заступник директора філії ЦТЛ АТ «Укрзалізничяя, Київ, Україна. E-mail: murakhovskyi@i.ua ID ORCID https://orcid.org/0000-0002-6148-7161

Лотиш Юлія Олександрівна, магістрант, кафедра управління експлуатаційною роботою, Украӥнський державний університет залізничного транспорту, Харків, Україна. E-mail: lotyshyuliia@i.ua ID ORCID https://orcid.org/0000-0002-9630-9090

Шабатура Владислав Вікторович, магістрант, кафедра управління експлуатачійною роботою, Украӥнський державний університет залізничного транспорту, Харків, Україна. E-mail: solinawow@gmail.com ID ORCID https://orcid.org/0000-0003-0618-3648 